\title{
JOURNAL OF AFRICAN HISTORY
}

\begin{tabular}{lll}
\hline VOL. III & 1962 & No. 2
\end{tabular}

\section{THIRD CONFERENCE ON AFRICAN HISTORY AND ARCHAEOLOGY \\ School of Oriental \& African Studies \\ University of London \\ 3-7 JULY I96I}




\section{FOREWORD}

THE third in a series of Conferences on African History and Archaeology, held at four-year intervals, took place at the School of Oriental and African Studies, University of London, from $3^{\text {rd }}$ to 7 th July $196 \mathrm{I}$. As is the custom at these Conferences, no papers were read. The whole of the four days available were devoted to discussion, in plenary session, of papers which had been submitted and circulated in advance. These were grouped according to periods and topics, ${ }^{1}$ each of which became the subject for discussion for a specific period of the conference.

This method of operation makes it possible to cover a great deal of ground within a limited period of time. But it creates problems when it comes to preparing the proceedings of the conference for publication. Notwithstanding the generous assistance afforded by the School of Oriental and African Studies, it was not possible to arrange for the complete publication of the proceedings of either of the two earlier conferences. In the case of the first conference, in $1953,{ }^{2}$ it was possible to publish seventeen out of the thirty-three papers that had been submitted, the gist of the remainder being incorporated in specially written surveys which also summarized the relevant discussions. For the 1957 conference, the discussions at which extended over three days (as against two in 1953), seventy papers were submitted and circulated. It was eventually possible to print no more than a single general account of the conference in which an attempt was made to summarize both the gist of the papers and of the discussion upon them. ${ }^{3}$ The editor of this report was thus faced with formidable problems of compression, and some two years elapsed before it finally appeared.

For publication of the I96I conference, it was resolved to make use of the facilities of the Fournal of African History (itself a child of the second conference). But this third conference was on an even greater scale than its predecessor. 184 persons attended or presented papers in absentia; no less than 113 papers were submitted and circulated $;{ }^{4}$ and the discussions were extended over four days. Even though an issue of the fournal disposes

1 These were: (1) The history and archaeology of Africa before the nineteenth century; (2) The history of Africa in the nineteenth century; (3) The twentieth-century history of Africa; (4) The history of food-crops in Africa; (5) Linguistics and historical research;

(6) Serology and historical research; and (7) Pre-colonial trade and trade-routes in Africa.

'See History and Archaeology in 'Africa; Report of a Conference held in Fuly 1953 at the

School of Oriental and African Studies, S.O.A.S. (London, 1955), 99.

'History and Archaeology in Africa; Second Conference held in July 1957 at the School of Oriental and African Studies, edited by D. H. Jones, S.O.A.S. (London, 1959), 58.

- See the list on pp. 367-74. 
of considerably more space than was available for the previous conference reports, selection and summary have once again proved necessary.

The editorial task was to some extent facilitated, however, by the fact that many of the papers were never intended by their authors for publication. Others, which might otherwise have been chosen, are to appear (or have appeared) elsewhere as articles or will be incorporated in books. Nevertheless, the task of selection still remained formidable and invidious. It was first decided to exclude from consideration all papers which were in effect no more than progress reports on work undertaken since 1957 . Among the papers remaining, certain themes seemed to stand out, and the final choice of papers for publication was made in illustration of these themes. However, other eyes might well have selected other papers, or even other themes of equal or greater importance. In any case the selection left untouched many matters of interest and significance which had been touched upon during the conference and its discussions. The Editors, who had also fulfilled the roles of Chairman and Secretary of the conference, therefore invited a colleague, $\mathrm{Dr}$ Richard Gray-who was present throughout the conference and was given access to the transcripts of its discussions, but who had not been in any way responsible for its organization-to write a general account of the Conference to serve as an introduction to this special Conference number of the fournal. The opportunity has also been taken to print the Concluding Statement and Resolutions of the Conference. 